\title{
Analisis Efektivitas Penerapan E-Absensi Terhadap Kinerja Aparatur Sipil Negara Di Sekretariat Daerah
}

\author{
${ }^{1}$ Muh. Yusuf Qamaruddin, ${ }^{2}$ M. Ishaq Iskandar \\ Universitas Muhammadiyah Palopo, Kota Palopo, Indonesia \\ Email: ${ }^{1}$ myusuf@umpalopo.ac.id, ${ }^{2}$ ishaqiskandar72@gmail.com
}

(Diterima: Juli 2021; Direvisi: Agustus 2021; Dipublikasikan: September 2021)

\begin{abstract}
ABSTRAK
Sekretariat daerah memiliki peranan penting dalam membantu melakukan perubahan dengan cara melakukan gerakan reformasi birokrasi. Pegawai Sekretariat Daerah Kota Palopo adalah mereka yang memiliki tugas dan tanggung jawab dalam memberikan pelayanan kepada masyarakat, membantu pemerintah daerah dalam menjalankan tugas pemerintahan serta diberi tugas pemerintahan berdasarkan peraturan perundang-undangan yang berlaku. Penelitian ini dilakukan untuk melihat sejauh mana Pengaruh Efektivitas Penggunaan E-Absensi dan Pengawasan Kerja secara simultan Terhadap Kinerja ASN di Sekretariat Daerah Kota Palopo. Hasil penelitian menunjukkan bahwa didapatkan nilai $\mathrm{T}_{\text {hitung }}$ variabel E-Absensi sebesar 9.412 dan $\mathrm{T}_{\text {tabel }}$ sebesar 1,671 atau 9.412>1,671 dan nilai signifikan E-Absensi 0,000 $<0,05$ ( $\mathrm{H}_{0}$ ditolak dan $\mathrm{H}_{1}$ diterima). Sehingga dapat diartikan bahwa E-Absensi berpengaruh positif dan signifikan terhadap Kinerja ASN (Y). di Sekretariat Daerah Kota Palopo.
\end{abstract}

\section{Kata Kunci: Efektivitas, E-Absensi, Kinerja}




\section{PENDAHULUAN}

Peningkatan kinerja pegawai merupakan hal yang sangat penting untuk diperhatikan bagi setiap instansi atau perusahaan. Kinerja pegawai sangat mempengaruhi kemajuan suatu instansi atau perusahaan. Salah satu faktor yang menentukan kinerja pegawai yakni kualitas sumber daya pegawai. Menurut Rukayat, (2017) mengungkapkan bahwa peningkatan kualitas pegawai sangat penting dilakukan secara terencana, terarah dan berkesinambungan guna menciptakan pegawai yang memiliki integritas dan profesionalisme dalam bekerja sehingga segala bentuk tanggung jawab dapat diselesaikan secara maksimal.

Salah satu unsur penting yang harus diperhatikan dalam meningkatkan kinerja pegawai yakni menjaga kedisiplinan pegawai dalam bekerja. Menurut Soejono, (2011) menyatakan bahwa kedisiplinan pegawai dalam sebuah instansi atau perusahaan dapat dikatakan baik apabila memenuhi aspek ketepatan waktu, ketaatan pada aturan dan kemampuan memelihara peralatan kantor. Berdasarkan teori tersebut dapat dipahami bahwa konsep kedisiplinan sangat menentukan kualitas sumber daya pegawai dalam bekerja. Sekretariat Daerah Kota Palopo merupakan salah satu Organisasi Perangkat Daerah (OPD) pemerintahan yang ada di Kota Palopo. Sekretariat Daerah (Setda) tersebut memiliki pegawai yang profesional dan berpengalaman di bidangnya masing-masing. Sekretariat daerah memiliki peranan penting dalam membantu melakukan perubahan dengan cara melakukan gerakan reformasi birokrasi. Sekretariat Daerah dipimpin oleh sekretaris daerah yang bertugas membantu pimpinan daerah dalam menjalankan tugas seperti membuat kebijakan dan sebagainya. Pegawai Sekretariat Daerah Kota Palopo adalah mereka yang memiliki tugas dan tanggung jawab dalam memberikan pelayanan kepada masyarakat, membantu pemerintah daerah dalam menjalankan tugas pemerintahan serta diberi tugas pemerintahan berdasarkan peraturan perundang-undangan yang berlaku. Berdasarkan peraturan perundangundangan tentang Kepegawaian, yaitu Undang-Undang Nomor 5 Tahun 2014 tentang Aparatur Sipil Negara bahwa pegawai Aparatur Sipil Negara (ASN) berperan sebagai perencana, pelaksana dan pengawas penyelenggaraan tugas umum pemerintahan dan pembangunan nasional melalui pelaksanaan kebijakan dan pelayanan publik yang profesional, bebas dari intervensi politik, serta bersih dari praktek korupsi, kolusi, dan nepotisme.

Berdasarkan undang-undang tersebut dapat diketahui bahwa pada dasarnya pegawai ASN terkhusus pegawai Sekretariat Daerah Kota Palopo memiliki tugas dan tanggung jawab yang besar dalam menjalankan amanah pemerintahan. Eksistensi pegawai tersebut berperan penting dalam membantu melayani masyarakat Kota Palopo. Sehingga roda pemerintahan dapat berjalan sesuai dengan koridor yang seharusnya. Oleh karena itu, pegawai Sekretariat Daerah Kota Palopo dituntut memiliki profesionalisme dan kedisplinan yang tinggi guna menciptakan kinerja pegawai yang 
optimal. Akan tetapi, belakangan permasalahan atau fenomena yang muncul di kalangan pegawai Sekretariat Daerah Kota Palopo yakni masih adanya pegawai yang datang terlambat, adanya pegawai yang tidak ditempat pada saat jam kerja, dan masih adanya pegawai yang datang ke kantor tetapi tidak langsung mengerjakan tugas dan tanggung jawabnya. Permasalahan tersebut menjadi permasalahan krusial di Sekretariat Daerah Kota Palopo. Salah satu upaya yang dilakukan pemerintah dalam meningkatkan kedisiplinan pegawai yakni dengan melakukan penerapan elektronik absensi. Fasilitas tersebut digunakan untuk memantau kehadiran pegawai yang ada di Sekretariat Daerah Kota Palopo pada khususnya. Penerapan sistem absensi tersebut pada dasarnya tidak terkait langsung dalam meningkatkan kinerja pegawai, namun digunakan sebagai alat untuk memantau dan mengontrol kedisplinan pegawai dalam bekerja. Menurut penelitian yang dilakukan oleh Setiawan, (2011) mengatakan bahwa sistem absensi Automatic Fingerprint Identification System (AFIS) berpengaruh terhadap peningkatan disiplin kerja. Hal tersebut sejalan dengan asumsi yang dikemukakan oleh Jayusman et al., (2021) yang mengatakan bahwa sistem elektronik absensi sangat membantu dalam pengawasan kerja pegawai. Berdasarkan asumsi tersebut dapat dipahami bahwa sistem elektronik absensi pada dasarnya membantu pimpinan dalam melakukan pengawasan secara berkala kepada pegawai yang bekerja. Sehingga dengan adanya fasilitas tersebut dapat membantu meningkatkan disiplin kerja di Sekretariat Daerah Kota Palopo.

\section{TINJAUAN PUSTAKA}

Organisasi pemerintahan daerah merupakan lembaga yang menjalankan roda pemerintahan dengan sumber legitimasi yang berasal dari masyarakat. Oleh karena itu, kepercayaan yang diberikan oleh masyarakat kepada penyelenggara pemerintah harus diimbangi dengan kinerja yang baik, sehingga pelayanan dapat ditingkatkan secara efektif dan menyentuh pada masyarakat. Hal ini semakin diperkuat dengan adanya pemberlakuan sistem desentralisasi pada tata pemerintahan dalam era otonomi daerah.

Otonomi Daerah menuntut pemerintah daerah untuk dapat memberikan pelayanan yang sebaikbaiknya kepada masyarakat. Salah satu bentuk pelayanan tersebut adalah memberikan informasi keuangan yang transparan dan akuntabel. Seperti yang telah dikemukakan oleh Wardono, (2012) yang menyatakan bahwa pemberian otonomi kepada daerah dimaksudkan untuk meningkatkan dayaguna dan hasil guna penyelenggaraan pemerintah di daerah, terutama dalam pelaksanaan pembangunan dan pelayanan terhadap masyarakat serta untuk meningkatkan pembinaan kestabilan politik dan kesatuan bangsa.

Undang-undang Nomor 23 Tahun 2014 tentang Pemerintahan Daerah telah ditetapkan untuk mengganti UU Nomor 32 Tahun 2004 yang telah disesuaikan dengan perkembangan keadaan, ketatanegaraan, dan tuntutan penyelenggaraan pemerintahan 
daerah. Muatan UU Pemerintahan Daerah tersebut membawa banyak perubahan dalam penyelenggaraan pemerintahan. Salah satunya adalah pembagian urusan pemerintahan daerah. Berdasarkan UU Nomor 23 tahun 2014 klasifikasi urusan pemerintahan terdiri dari tiga urusan yakni urusan pemerintahan absolut, urusan pemerintahan konkuren, dan urusan pemerintahan umum. Urusan pemerintahan absolut adalah urusan pemerintahan yang sepenuhnya menjadi kewenangan Pemerintah Pusat. Urusan pemerintahan konkuren adalah urusan pemerintahan yang dibagi antara Pemerintah Pusat dan Daerah Provinsi dan Daerah kabupaten/kota.

Urusan pemerintahan umum adalah urusan pemerintahan yang menjadi kewenangan Presiden sebagai kepala pemerintahan. Menurut Prihayanto \& Ratnawati, (2011), pegawai merupakan suatu perbuatan, prestasi, dan penampilan umum dan keterampilan dan kinerja dengan asal kata kerja berarti aktifitas yang dilakukan oleh seseorang atau organisasi dalam menjalankan tugas yang menjadi pekerjaannya. Secara umum kinerja merupakan proses tingkah laku seseorang sehingga ia menghasilkan sesuatu yang menjadi tujuan dari pekerjaannya. Perbedaan kinerja antara seseorang dengan lainnya di dalam situasi kerja adalah karena perbedaan karakteristik dari individu. Di samping itu, seseorang dapat menghasilkan kinerja yang berbeda di dalam situasi yang berbeda pula. Semua ini menerangkan bahwa kinerja pada dasarnya dipengaruhi oleh beberapa faktor diantaranya kepemimpinan, motivasi, maupun organisasi. Upaya untuk menjaga dan meningkatkan kinerja adalah hal yang mutlak dilakukan dalam rangka mewujudkan tujuan organisasi tersebut.

Wardono, (2012) mengatakan bahwa ada beberapa unsur atau faktor yang mendukung kinerja yaitu faktor internal individual dan faktor eksternal. Faktor internal lebih banyak ditimbulkan oleh dorongan yang muncul dari diri para pekerja itu sendiri, sementara faktor eksternal ditimbulkan oleh dorongan dari luar diri mereka sendiri. Contoh misalnya motivasi kerja bagi pegawai untuk merangsang pegawai agar lebih giat dan bersemangat dalam menyelesaikan tugas-tugasnya. Disamping motivasi, kedisiplinan juga mempengaruhi kinerja pegawai. Tidak dapat dipungkiri bahwa kedisiplinan sering menimbulkan permasalahan tersendiri bagi organisasi umumnya. Kedisiplinan pegawai mutlak diperlukan agar seluruh aktivitas yang sedang dan akan dilaksanakan berjalan sesuai dengan mekanisme yang telah ditentukan (Iriani, 2010). Selain kedisiplinan, terdapat aspek lain yang juga mempengaruhi kinerja pegawai yaitu gaya kepemimpinan. Menurut Kasmir et al., (2011) Gaya Kepemimpinan yang ada di organisasi pemerintahan juga sangat bepengaruh terhadap kinerja pegawai. Tinggi rendahnya kinerja pegawai tergantung dari figur pemimpinnya dan cara pemimpin tersebut memimpin bawahannya. Menurut Natassia et al., (2010) menyatakan bahwa pemimpin yang baik adalah merupakan hal yang sangat penting dalam bisnis, pemerintahan, organisasi serta kelompok yang menciptakan pola hidup, bekerja dan 
bermain, serta pemimpin mempunyai fungsi sebagai penggerak atau dinamisator dan koordinator dari sumber daya manusia, sumber daya alam, semua dana dan sarana yang disiapkan. Sebab pemimpin sebagai faktor yang mengarahkan organisasi dan juga memberi contoh perilaku terhadap pegawai, peran pemimpin sangat menentukan kemajuan dan kemunduran organisasi.

Salah satu indikator kinerja pegawai yang lainnya adalah komitmen organisasi. Pegawai dengan komitmen yang tinggi dapat diharapkan akan memperlihatkan kinerja yang optimal. Seseorang yang bergabung dalam organisasi pemerintahan dituntut adanya komitmen dalam dirinya. Seperti yang telah dikemukakan oleh Sutrisno \& Purnomosidhi, (2013) Salah satu penentu keberhasilan suatu organisasi adalah komitmen pegawai pada organisasi tempat mereka bekerja. Komitmen merupakan suatu wujud (bentuk) penerimaan dan berpihaknya seseorang pada organisasi dalam bentuk kemauan dan hasrat untuk melaksanakan kewajiban yang dibebankan. Adanya komitmen yang tinggi, maka dapat menunjang kinerja suatu organisasi. Komitmen mencakup juga keterlibatan kerja. Hal ini disebabkan karena antara keterlibatan kerja dengan komitmen organisasi sangat erat hubungannya. Keterlibatan kerja sebagai derajat kemauan untuk menyatukan dirinya dengan pekerjaan, menginvestasikan waktu, kemampuan dan energinya untuk pekerjaan, dan menganggap pekerjaannya sebagai bagian utama dari kehidupannya.

Sutrisno \& Purnomosidhi, (2013) mengungkapkan dua pandangan terkait komitmen organisasional yaitu, affective dan continuence. Komitmen organisasi affective berhubungan dengan satu pandangan profesionalisme atau pengabdian pada profesi, sedangkan komitmen organisasi continuence berhubungan secara positif dengan pengalaman dan secara negatif dengan pandangan profesionalisme kewajiban sosial. Dua pandangan ini merupakan dimensi penting yang dianggap berpengaruh terhadap kinerja. Komitmen organisasi terbangun bila tiap individu mengembangkan tiga sikap yang saling berhubungan terhadap organisasi dan atau profesi meliputi identification yaitu pemahaman atau penghayatan dari tujuan organisasi, involment yaitu perasaan terlibat dalam suatu pekerjaan atau perasaan bahwa pekerjaannya adalah menyenangkan, dan loyality yaitu perasaan bahwa organisasi adalah tempat bekerja dan tempat tinggal.

\section{Konsep Perilaku Organisasi}

Perilaku organisasi adalah suatu studi yang menyangkut aspek-aspek tingkah laku manusia dalam suatu organisasi atau suatu kelompok tertentu dengan tujuan untuk mendeterminasi bagaimana perilaku manusia itu mempengaruhi usaha pencapaian tujuan-tujuan organisasi. Menurut Duncan \& Hoffman, (1981:7) penjelasannya sebagai berikut:

a. Studi perilaku organisasi termasuk di dalamnya bagianbagian yang relevan dari semua ilmu tingkah laku yang berusaha menjelaskan tindakan-tindakan manusia di dalam organisasi. 
b. Perilaku organisasi sebagaimana suatu disiplin ilmu mengenal bahwa individu dipengaruhi oleh bagaimana pekerjaan diatur dan siapa yang bertanggung jawab untuk pelaksanaannya. Oleh karenanya, ilmu ini memperhitungkan pula pengaruh struktur organisasi terhadap perilaku individu.

c. Walaupun dikenal adanya keunikan individu, namun perilaku organisasi masih memusatkan pada kebutuhan manajer untuk menjamin bahwa keseluruhan tugas pekerjaan bisa diselesaikan. Sehingga kesimpulannya ilmu ini mengusulkan beberapa cara agar usaha-usaha individu itu bisa terkoordinir dalam rangka mencapai tujuan organisasi.

\section{Perspektif budaya bangsa Indonesia dan perilaku organisasinya.}

Sejak dahulu kala, Indonesia terkenal akan keindahan alam dan keragaman budayanya. Hal ini terbukti dengan berbeda-bedanya suku bangsa antara daerah satu dengan yang lainnya. Perbedaan yang ada seharusnya dijadikan tolak ukur untuk bisa lebih bekerjasama dalam dalam mencapai tujuan Negara Indonesia. Akan tetapi, seiring dengan dunia luar yang terus berubah menuntut kita untuk harus dapat berinteraksi dengan negaranegara lain. Dunia dibawa dan didorong oleh perkembangan teknologi dan ilmu pengetahuan serta tertembusnya batas-batas negara dan batas-batas kebudayaan karena tersebarnya informasi dan lain-lain hubungan, membuat dunia makin kecil dan terbuka sehingga secara otomatis perubahan di dalam tubuh pemerintahan pun ikut berubah secara drastis.

Menurut Ikmal, perkembangan teknologi dan globalisasi informasi sangat berpengaruh dan berakibat pada terjadinya pergeseran tata nilai. Sehingga ada kecenderungan nilainilai kepahlawanan, keperintisan dan kesetiakawanan sosial mengalami penurunan dalam pengamalannya di setiap aspek termasuk kegiatan birokrasi. Tubuh pemerintahan atau disebut Birokrasi di Indonesia mengalami perubahan mengikuti arus globalisasi dan kecanggihan teknologi yang semakain pesat. Perubahan yang dimaksud adalah dengan munculnya konsep $e$ Government adalah penyelenggaraan pemerintahan berbasis (menggunakan) eletronik dalam rangka meningkatkan kualitas layanan publik secara efektif dan efisien. Penekanan disini adalah kepada "GOVERNMENT" bukan pada "e" (atau Teknologi Informasi)-nya. Jadi bukan ditentukan seberapa canggih teknologi yg dipakai di webserver-nya, bukan karena komputer-komputer di kantor menggunakan teknologi terbaru dan tercepat, jaringan yg hebat, atau dengan kata lain menggunakan investasi yang mahal sekali untuk membuat infrastuktur $e$-gov tersebut.

Penerapan e-Government di Indonesia mengalami kendala disebabkan salah satunya adalah 
pada komponen People (orangorang yg terlibat) terkait dengan perilaku organisasi yang terkesan masih tradisional dan prosedur kerja yang masih lama dan berbelit. Sementara itu, yang sangat mendasar tetapi memerlukan komitmen perubahan yang kuat adalah faktor budaya. Jajaran pemerintah di Indonesia sebenarnya cukup mudah dalam memperoleh akses teknologi, dan tidak kurang juga banyak pemimpin yang punya visi pengembangan layanan secara elektronik. Namun masalahnya adalah bahwa pemanfaatan $e$-gov sering terbentur dengan faktor budaya masyarakat yang masih kurang mendukung dalam pemanfaatan teknologi.

Faktor budaya diantara para birokrat dalam lembaga pemerintah inilah yang sering mengakibatkan kurangnya kesadaran dan penghargaan terhadap pentingnya $e$-gov. Yang sering muncul adalah ketakutan atau kekhawatiran yang berlebihan bahwa aplikasi e-gov akan mengancam jabatannya yang sudah mapan. Kita juga sering melihat bahwa integrasi diantara lembaga negara, Kementerian maupun non-kementerian masih selalu terkendala karena masingmasing tidak mau berbagi data dan informasi. Inilah kendala yang paling pokok bagi penerapan $e$-gov secara serius. Karena hambatan sikap dan cara berpikir yang sempit diantara pejabat pemerintah sendiri, upaya integrasi masih menyisakan bentukan sistem berupa pulau-pulau database yang sulit untuk dikomunikasikan apalagi diintegrasikan.

\section{METODE PENELITIAN}

Jenis penelitian yang digunakan dalam penelitian ini adalah penelitian kuantitatif. Menurut Sugiyono penelitian kuantitatif dapat diartikan sebagai metode penelitian yang berlandaskan pada filsafat positivisme, digunakan untuk meneliti pada populasi atau sampel tertentu, teknik pengambilan sampel pada umumnya dilakukan secara random, pengumpulan data menggunakan instrumen penelitian, analisis data bersifat kuantitatif/statistik, dengan tujuan untuk menguji hipotesis yang telah ditetapkan penelitian menggunakan.

Menurut Sugiyono, (2017), populasi adalah wilayah generalsasi yang terdiri atas, objek atau subjek yang mempunyai kualitas dan karakteristik tertentu yang diterapkan oleh peneliti untuk dipelajari dan kemudian disimpulkan. Populasi dalam penelitian ini yakni seluruh pegawai yang ada di sekretariat pegawai kota Palopo sebanyak 153 orang. Teknik penentuan sampel yang digunakan dalam penelitian ini yaitu random sampling. Jumlah sampel yang digunakan dalam penelitian ini denganmenggunakan rumus Slovin dengan jumlah sampel sebanyak 60 orang.

Penelitian ini akan dilaksanakan selama 3 bulan dimana lokasi penelitian dilakukan di Sekretariat Daerah Kota Palopo, Sulawesi Selatan.

Teknik yang digunakan penulis yaitu Angket (kuesioner) merupakan teknik pengumpulan data yang 
dilakukan dengan cara memberi seperangkat pertanyaan atau pernyataan tertulis kepada responden untuk dijawabnya. Kuesioner merupakan teknik pengumpulan data yang efesien bila peneliti tahu dengan pasti variabel yang akan diukur dan tahu apa yang bisa diharapkan dari responden. Kuesioner dapat berupa pertanyaan atau pernyataan tertutup atau terbuka, dapat diberikan kepada responden secara langsung. Adapun analisis data yang digunakan dalam penelitian ini yaitu analisis regresi sederhana, uji $t$ dan koefisien determinasi.

\section{HASIL PENELITIAN}

\section{Analisis Regresi Sederhana}

Tabel 1. Regresi Sederhana Coefficients(a)

\begin{tabular}{|c|c|c|c|c|c|c|}
\hline \multirow{2}{*}{\multicolumn{2}{|c|}{$\begin{array}{l}\text { M } \\
\text { od } \\
\text { el }\end{array}$}} & \multicolumn{2}{|c|}{$\begin{array}{l}\text { Unstandar } \\
\text { dized } \\
\text { Coefficient } \\
\text { s }\end{array}$} & $\begin{array}{c}\text { Stand } \\
\text { ardize } \\
d \\
\text { Coeffi } \\
\text { cients }\end{array}$ & $t$ & $\begin{array}{l}\text { Si } \\
\text { g. }\end{array}$ \\
\hline & & B & $\begin{array}{c}\text { Std. } \\
\text { Erro } \\
r\end{array}$ & Beta & B & $\begin{array}{l}\text { St } \\
d . \\
\text { Er } \\
\text { ro } \\
r\end{array}$ \\
\hline 1 & $\begin{array}{l}\text { (Con } \\
\text { stant } \\
\text { E- } \\
\text { Abse } \\
\text { nsi }\end{array}$ & $\begin{array}{r}705 \\
.43 \\
6 \\
8.4 \\
21\end{array}$ & $\begin{array}{r}254 \\
9.16 \\
1 \\
20.4 \\
43\end{array}$ & .055 & $\begin{array}{l}.2 \\
7 \\
7 \\
.4 \\
1 \\
2\end{array}$ & $\begin{array}{l}.0 \\
0 \\
0 \\
.0 \\
0 \\
0\end{array}$ \\
\hline
\end{tabular}

a Dependent Variable: Kinerja ASN

Persamaan Regresinya sebagai berikut:

$\mathrm{Y}=\mathrm{a}+\mathrm{bx}_{1}+\mathrm{e}$

$$
\mathrm{Y}=705.436+8.421 \mathrm{X}_{1}+\mathrm{e}
$$

Angka-angka ini dapat diartikan sebagai berikut:

a. Konstanta sebesar positif 705.436; artinya jika E-Absensi $\left(\mathrm{X}_{1}\right)$ dan Pengawasan Kerja $\left(\mathrm{X}_{2}\right)$ nilainya 0 , maka Kinerja ASN (Y) nilainya positif yaitu sebesar 705.436. b. Koefisien regresi E-Absensi $\left(\mathrm{X}_{1}\right)$ sebesar positif 8.421 jika E-Absensi $\left(\mathrm{X}_{1}\right)$ mengalami kenaikan nilai 1, maka Kinerja ASN (Y) akan mengalami peningkatan sebesar 8.421. Koefisien bernilai positif artinya terjadi hubungan positif antara E-Absensi $\left(\mathrm{X}_{1}\right)$ terhadap Kinerja ASN (Y).

\section{Uji Parsial (Uji t)}

Tabel 2. Regresi Sederhana Coefficients(a)

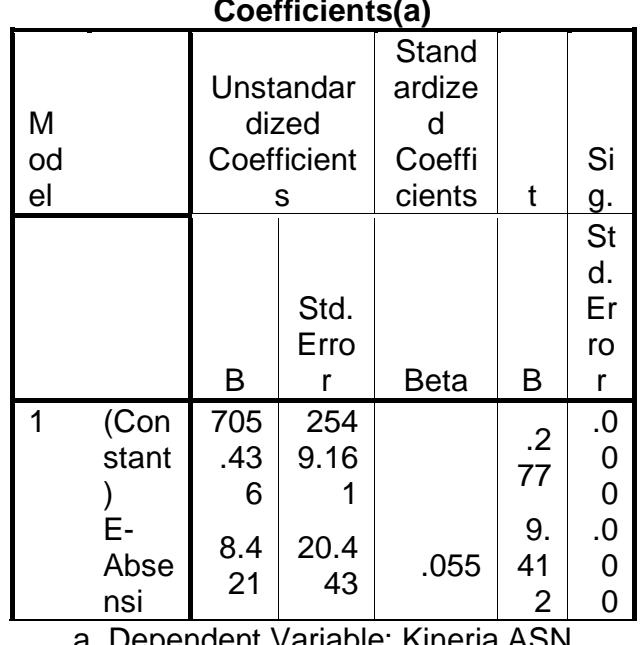

Dari hasil uji parsial (Uji-t) tersebut jika dilihat dari nilai $\mathrm{t}_{\text {hitung }}$ $>\mathrm{t}_{\text {tabel }}$ dan nilai signifikan $<0,05$ ( $\mathrm{H}_{0}$ ditolak dan $\mathrm{H}_{1}$ diterima) maka variabel E-Absensi $\left(\mathrm{X}_{1}\right)$ berpengaruh signifikan terhadap variabel Kinerja ASN (Y). Hasil dari output "Coefficients" didapatkan nilai $T_{\text {hitung }}$ variabel $\mathrm{E}$ Absensi sebesar 9.412 dan $\mathrm{T}_{\text {tabel }}$ sebesar 1,671 atau $9.412>1,671$ dan nilai signifikan E-Absensi $0,000<0,05 \quad\left(\mathrm{H}_{0}\right.$ ditolak dan $\mathrm{H}_{1}$ diterima). Sehingga dapat diartikan bahwa E-Absensi berpengaruh positif dan signifikan terhadap Kinerja ASN (Y). 


\section{PEMBAHASAN}

Hasil penelitian ini sesuai dengan teori yang dijadikan sebagai landasan penelitian yaitu teori Hasibuan, (2007:194) mengatakan bahwa salah satu faktor yang mempengaruhi tingkat kedisiplinan pegawai yaitu faktor waskat (pengawasan melekat) Pengawasan melekat yang dimaksud yaitu penerapan sistem e-absensi yang merekam dan memantau kehadiran pegawai setiap harinya. Hal ini berarti bahwa penerapan E-Absensi di Kantor Sekretariat Daerah Kota Palopo menjadi salah satu variabel yang berpengaruh terhadap peningkatan kinerja ASN di sekretariatan Kota Palopo. Semakin tinggi efektivitas penerapan EAbsensi maka semakin kuat pengaruhnya terhadap kinerja ASN di Sekretariatan Kota Palopo.

Penelitian ini sejalan dengan penelitian yang dilakukan oleh Setiawan, (2011) yang mengatakan bahwa sistem E-Absensi berbasis Automatic Fingerprint Identification System (AFIS) memiliki pengaruh yang positif dan signifikan terhadap kedisiplinan dan kinerja pegawai. Pentingnya penerapan E-Absensi secara efektif menyebabkan variabel ini wajib dijadikan salah satu variabel penting dalam meningkatkan kinerja pegawai di Sekretariatan Kota Palopo.

Selain itu, penelitian ini sejalan dengan asumsi yang disampaikan oleh Jayusman et al., (2021) bahwa penerapan E-Absensi sangat membantu dalam proses pengawasan dan tingkat kedisplinan pegawai dalam bekerja. Sehingga dengan demikian, peningkatan kualitas dan kinerja ASN di Kantor Sekretariat
Daerah Kota Palopo dapat dilakukan melalui penerapan E-Absensi secara efektif. Sehingga kualitas kinerja pegawai yang tinggi juga menjadi salah satu patokan pegawai dalam beretos kerja tinggi. ASN atau pegawai yang memiliki kinerja yang baik dan positif pasti juga memiliki etos kerja yang baik dan positif pula.

\section{KESIMPULAN}

Variabel E-Absensi $\left(\mathrm{X}_{1}\right)$ berpengaruh positif dan signifikan terhadap Kinerja Aparatur Sipil Negara (Y) di Sekretariat Daerah Kota Palopo. Dari hasil penelitian ini disarankan bagi Sekretaris Daerah Kota Palopo agar meningkatkan penerapan E-Absensi dalam rangka meningkatkan kinerja pegawai serta bagi ASN Sekretariat Daerah Kota Palopo sebaiknya meningkatkan kinerja melalui kedisiplinan dalam bekerja dan peningkatan kualitas kerja.

\section{DAFTAR PUSTAKA}

Duncan, G. J., \& Hoffman, S. D. (1981). The incidence and wage effects of overeducation. Economics of Education Review, 1(1), 75-86.

Hasibuan, M. S. P. (2007). Manajemen Sumber Daya Manusia, cetakan kesembilan. Jakarta: PT Bumi Aksara.

Iriani, N. I. (2010). Motivasi Intrinsik, Motivasi Ekstrinsik dan Disiplin Kerja Pengaruhnya terhadap Kinerja Pegawai pada Kantor Dinas Pendidikan Kabupaten Sambas. Jurnal Aplikasi Manajemen, 8(2), 561-569.

Jayusman, H., Setyorini, W., \& Prakasa, A. D. (2021). 
Pengaruh Lingkungan Kerja Fisik Terhadap Kinerja Karyawan Teras Kopi Sukamara. Magenta, 9(2), 7582.

Kasmir, J., Senthilkumar, S. R., Britto, S. J. L., \& Raj, J. M. (2011). Identification of fungal endophytes from Orchidaceae members based on nrITS (internal transcribed spacer) region. International Research Journal of Biotechnology, 2(6), 139-144.

NATASSIA, R., Putri, Y. E., \& Oposma, M. (n.d.). Pengaruh Kepemimpinan dan Motivasi Kerja terhadap Kinerja Karyawan pada Perusahaan Daerah Air Minum (Pdam) Kota Padang. Pendidikan Ekonomi, 2(2), 29805.

Prihayanto, S., \& Ratnawati, I. (2011). Pengaruh Budaya Organisasi dan Motivasi Terhadap Kinerja Karyawan. Jurnal Skripsi Susandi Prihayanto.

Rukayat, Y. (2017). Kualitas pelayanan publik bidang administrasi kependudukan di kecamatan pasirjambu. Jurnal Ilmiah Magister Administrasi, 11(2).
Setiawan, A. (2011). Kualitas Perangkat Lunak Absensi Sidik Jari Dampaknya Terhadap Disiplin Dan Prestasi Kerja Di PT. Kagum Karya Husada Bandung. Universitas Komputer Indonesia.

Soejono, D. (2011). Strategi pengembangan agribisnis dan agroindustri sub sektor tanaman pangan di Kabupaten Situbondo. JSEP (Journal of Social and Agricultural Economics), 5(3), 54-60.

Sugiyono, P. D. (2017). Metode Penelitian Bisnis: Pendekatan Kuantitatif, Kualitatif, Kombinasi, dan R\&D. Penerbit $C V$. Alfabeta: Bandung.

Sutrisno, T., \& Purnomosidhi, B. (2013). Pengaruh budaya organisasi, komitmen organisasi, gaya kepemimpinan, dan kompetensi terhadap kinerja pemerintahan daerah (Studi empiris pada Kabupaten Bangkalan). InFestasi, 9(2), 123-136.

Wardono, M. N. S. (2012). Pengaruh Pendidikan Pelatihan Dan Motivasi Terhadap Kinerja Pegawai Di Kantor Kecamatan Semen Kabupaten Kediri. Jurnal Ilmu Manajemen, REVITALISASI, 1(2), 115-124. 